\title{
Effect of Bio-polymers on the properties of Mud Blocks
}

\author{
Manikanta.D \\ P.G. Student, Civill Engineering Department,, \\ Adhichunchanagiri Instittue of Technology,V.T.U University, Karnataka, India \\ Sanjith.J \\ Assistant professor, Department of Civil Engineering, \\ Adhichunchanagiri Instittue of Technology,V. T. U. University,Karnataka, India
}

\begin{abstract}
Soil or earth as an artifact is accessible in most areas of the planet. In developing countries, earth construction is economically the foremost economical means that of house construction with the smallest amount demand of resource. This thesis studies the result of proportion between soil and also the biopolymers on the properties of earth blocks sturdiness. It conjointly compares mechanical properties (Compressive strength \& Flexural strength) of stable earth blocks that are ready exploitation solely native soils (which is taken from Chikmagaluru area) and with the addition of biopolymers. Connected literature review shows that soil sorts, proportion between soil and biopolymers (Xanthan gum \& legume gum) quantity and compaction pressure applied to wet soil combine affects the standard of the mud block. Exploitation soil and biopolymers (Xanthan gum \& legume gum), 5 differing types of samples were ready. Tests were conducted on these samples so as to judge their performance like compressive strength, Flexural strength $\&$ Total water absorption on that the sturdiness of the blocks rely. Investigation was unconcealed that, out of all block samples, blocks that are created from $4 \mathrm{WD}$ of biopolymers (2\%Xanthan gum \& a pair of legume gum) and soil have compressive strength, Flexural strength and total water absorption values on top of the counseled minimum values for structural work
\end{abstract}

\section{INTRODUCTION}

The investigation of other materials for the development of low price housing has been the main target several of the many studies in many developing countries. the current rate of construction in developing countries per is usually decent to fulfill the wants of solely $100 \%$ of world wide web increase in population per annum. This can be partially owing to the inaccessibility and also the soaring prices of standard building materials. The direct uses of earth will not modification for wall construction in any kind has the disadvantage of low performance. As this shortage of building is changing into worse, additional efforts are being created to develop low cost, serviceable and energy economical construction materials for the development of cheap property buildings. Masonry structures is one among the foremost well-liked materials for housing construction owing to its helpful properties like sturdiness, comparatively low price, smart sound and warmth insulation, acceptable fireplace resistance, adequate resistance to weathering and encouraging look. The world interest regarding the atmosphere per has accumulated the employment of earth as a are the fact.

The shortcomings in the main are low mechanical characteristics, in adequate resistance to weathering and liability to volume amendment particularly within the case of clay. These disadvantages is improved to form the fabric compatible with desired application in Construction by combined chemical and mechanical action technically referred to as stabilization. Earth bricks have the flexibility to soak up atmospherically wetness that creates healthy atmosphere within a building for its occupants. Mud blocks supply variety of benefits which has accumulated utilization of native material and reducing the value of transportation because the production is with in place, makes quality housing obtainable to additional folks, and generates native economy rather than defrayal for import materials. Alternative blessings are quicker, Cheaper and easier construction technique leading to the lesser demand of experienced labor, smart strength, insulation and thermal low level of waste and cause no direct environmental pollution throughout the entire life cycle. One among the drawbacks of victimization earth soil alone as a cloth for construction as posited by is its sturdiness that is powerfully associated with its compressive strength. as a result of most soil in their natural condition lack the strength, dimensional stability and sturdiness needed for building construction. These properties are increased through stabilization. This analysis aims, also, the study of latest strategies of soil stabilization, with biopolymers, 
adapting the traditional data to enhance the sturdiness associated with the water action. This way, different solutions were obtained so as to enhance the performance of earth buildings in terms of resistance, particularly once to bear with water, reducing the water permeableness and keeping the vapor permeableness of the fabric, one among the most blessings of earth construction.

\section{MATERIALS USED}

\subsection{SOIL}

Soil is made from bed-rock as results of terribly long processes of weathering and also the terribly complicate manner during which particles migrate. These end in an infinite variety of styles of soil, with infinite variations in characteristics. Dirt or agricultural soil, that contains a high proportion of organic matter, forms a layer higher than that of the bed-rock, which can be additional or less weather-beaten. Once the higher layers of earth are created from loose material and contain very little organic matter, they will be used for building. Composition - Soils used for making mud blocks are made up of varying proportions of four types of material: gravels (0-40\%), sands (25-80\%), silts (10-25\%) and clays ( $8-30 \%)$.

\subsection{BIO POLYMERS}

Biopolymers are polymers created by living organisms. Since they're polymers, Biopolymers contain monomeric units that are covalently secure to create larger structures. There are 3 main categories of biopolymers supported the differing monomeric units used and also the structure of the biopolymer fashioned. Polynucleotide's long polymers that are recomposed of thirteen or additional ester monomers, polypeptides short polymers of amino acids, and Poly saccharides that are usually linear secure chemical compound saccharide structures.

\section{Types of Biopolymers}

1. Xanthan gum

2. Guar gum

\section{XANTHAN GUM}

Xanthan gum, a fancy polymer created by a bacteria, was one in every of the primary commercially victorious microorganism polysaccharides to be created by fermentation. The xanthan chemical compound building blocks or

\begin{tabular}{|l|l|l|}
\hline S1 No. & Properties & Result \\
\hline 1 & Specific gravity & 2.61 \\
\hline 3 & Optimum moisture content & $11.1 \%$ \\
\hline 4 & Maximum dry density & $1.832 \mathrm{gm} / \mathrm{cc}$ \\
\hline 5 & Coefficient of Permeability (k) & $9.217 \times 10-4$ \\
\hline & Atterberg limits & $25 \%$ \\
& a) Liquid limit b) Plastic limit & $23 \%$ \\
\hline & & $43.7 \%$ \\
\hline
\end{tabular}

Table 1:- Properties of Xanthan Gum 
"repeat units" contain 5 completely different sugar teams created by the bacteria genus Xanthomona scampestris. it's used extensively in each the food and therefore the non-food sectors. samples of industrial applications embody oil recovery (provides viscousness management in drilling mud fluids), mineral extraction(used as a biocide), paper producing (used as a modifier), agriculture (acts as plant growth stimulator), prescribed drugs (being evaluated for sustained drug release), and cosmetics (controls mud release).

Food applications embody gelling agents for cheese spreads, ice creams, puddings, and different deserts. Xanthan gum is created by feeding sugar to the bacterium genus Xanthomonas campestris.

The bacterium soaks up the sugar and metabolise it into an additional complicated sugar, during this case xanthan gum. The structure of latest sugar has distinctive properties that create it associate degree economical material or stabilizer oncecombined with different ingredients.

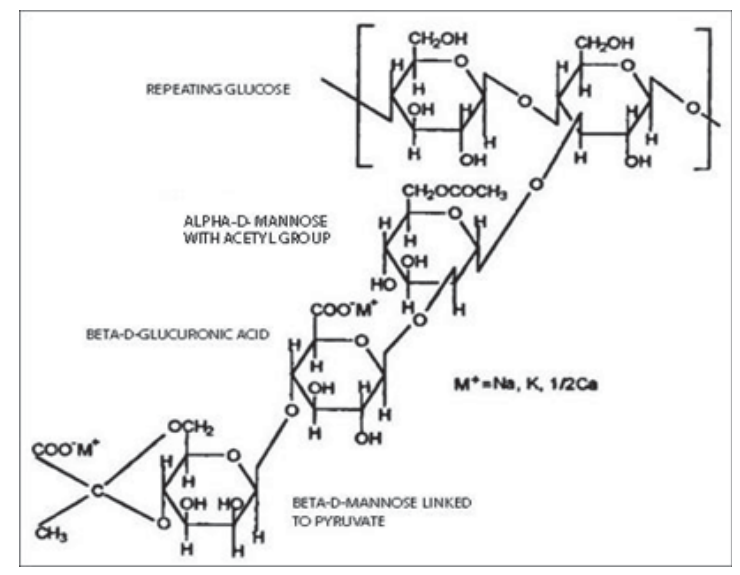

Fig 1: Chemical structure of Xanthan gum

\section{GUAR GUM:-}

Guar gum powder is extracted from the Cyamopsis tetragonolobus seed when a period process. the foremostnecessary property of gum is its ability to hydrate speedily in cold water to attain uniform and terribly highconsistency at comparatively low concentrations. Its mixture nature offers glorious thickening to conveyanswer.Guar gum, either changed or unqualified is extremely versatile and economical natural chemical compound covering variety of applications in numerous industries like food, beverages, prescription drugs, cosmetics, paper, textile, construction, oil and well drilling, miming etc., owing to its value effective emulsifying and thickening properties. Neelkanth polymers produces high consistency Cyamopsis tetragonolobus refined splits, gumpowder, gum derivatives, quick hydrating gum, H.P Cyamopsis tetragonolobus and high.

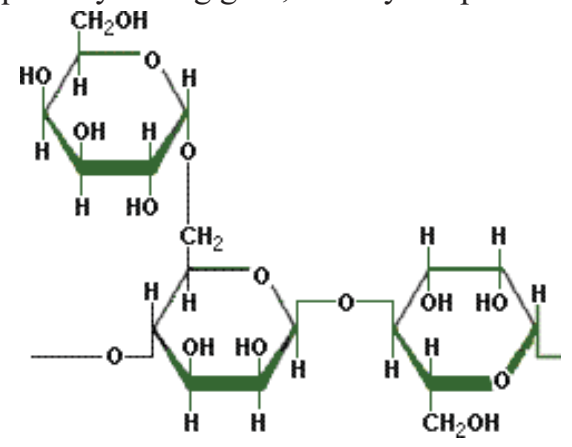

Fig 2 : Chemical structure of Guar gum

\section{METHODOLOGY}


Methodology is the systematic theoretical analysis of the methods applied to a field of study. It comprises the theoretical analysis of the body of methods principles associated with a branch of knowledge. Typically, it encompasses concept such as paradigm, theoretical model, phases and quantitative and qualitative techniques.

1.EXTRACTION from the quarry or pit.

2.DRYING by spreading in skinny layers or passing through a hot-air cyclone.

3. PULVERIZING to interrupt up lumps of clay.

4.SCREENING to eliminate undesirable components when general preparation.

5. MEASURING OUT the dry soil by weight or by volume with a read to intermixture it with water and/or with stabilizer.

6.DRY intermixture to maximize the effectiveness of a stabilizer in powder kind.12

7.WET intermixture to feature water by spraying when adequate dry intermixture, or directly within the kind of a liquid stabilizer.

8. REACTION throughout variable hold-back time relying on the nature of the stabilizer; terribly short for cement, longer for lime.

9.ACTIVITY OUT the quantity of mixed material for optimum block density.

10.COMPRESSION of the mixed material.

11.REMOVING the block from the mould.

12.WET activity, the length of your time betting on the climate and also the nature of the stabilizer.

13. DRYING OUT that ought to change the standard needed to be achieved.

14.STOCKING of the merchandise prepared to be used.

- Experimental design work-Different Mix Proportions

In the project, we are changing the proportions of soil and biopolymers and considering the weight of single brick as $5 \mathrm{~kg}$.

\begin{tabular}{|c|c|c|c|}
\hline PROPORTION & SOIL & XANTHANGUM & GUAR GUM \\
\hline 1 & $100 \%$ & $00 \%$ & $00 \%$ \\
\hline 2 & $98 \%$ & $1 \%$ & $1 \%$ \\
\hline 3 & $96 \%$ & $2 \%$ & $2 \%$ \\
\hline 4 & $94 \%$ & $3 \%$ & $3 \%$ \\
\hline 5 & $92 \%$ & $4 \%$ & $4 \%$ \\
\hline
\end{tabular}

Table 2:- Proportion of mixes.

- Calculation for quantity of materials

Quantity of Materials Required (kg) for blocks.

\begin{tabular}{|c|c|c|c|}
\hline PROPORTION & SOIL & XANTHAN GUM & GUAR GUM \\
\hline 1 & $5 \mathrm{~kg}$ & $00 \mathrm{~kg}$ & $00 \mathrm{~kg}$ \\
\hline 2 & $4.9 \mathrm{~kg}$ & $0.05 \mathrm{~kg}$ & $0.05 \mathrm{~kg}$ \\
\hline 3 & $4.8 \mathrm{~kg}$ & $0.1 \mathrm{~kg}$ & $0.1 \mathrm{~kg}$ \\
\hline 4 & $4.7 \mathrm{~kg}$ & $0.15 \mathrm{~kg}$ & $0.15 \mathrm{~kg}$ \\
\hline 5 & $4.8 \mathrm{~kg}$ & $0.2 \mathrm{~kg}$ & $0.2 \mathrm{~kg}$ \\
\hline
\end{tabular}

Table 3:- Calculation for quantity of materials.

Number of Blocks required for each proportion 
Blocks are required for each test

\begin{tabular}{|c|c|c|c|}
\hline SL NO. & TESTS & PROPORTIONS & TOTAL \\
\hline 1 & Compressive Strength & 5 & 15 \\
\hline 2 & Flexural Strength & 5 & 15 \\
\hline 3 & Water Absorption & 5 & 15 \\
\hline 4 & Shape Test & 5 & 15 \\
\hline 5 & Weight & 5 & 15 \\
\hline
\end{tabular}

Table 4:- Number of Blocks required for each proportion

Total quantity of materials required Soil: $5 \times 90+10 \%$ extra $=490 \mathrm{~kg}$

Biopolymers

$\square \quad$ Xanthan gum: $3 \mathrm{~kg}$

$\square$ Guar gum: $3 \mathrm{~kg}$

- Water content for different proportions

Amount of water content for different proportions was not available in IS codes and any articles were the reference was taken. It was decided with the no. of trial and error methods.

\section{RESULT}

- $\quad$ Compressive strength of pure earthen block $(\mathrm{E})$ sample $=3.51 \mathrm{MPa}$.

- Compressive strength for $2 \%$ addition of biopolymers $=4.2 \mathrm{MPa}$.

- Compressive strength for $4 \%$ addition of biopolymers $=5.03 \mathrm{MPa}$.

- Compressive strength for $6 \%$ addition of biopolymers $=3.49 \mathrm{MPa}$.

- Compressive strength for $8 \%$ addition of biopolymers $=3.42 \mathrm{MPa}$.

- $\quad$ Flexural strength of pure earthen block (E) sample $=0.53 \mathrm{MPa}$.

- Flexural strength for $2 \%$ addition of biopolymers $=0.54 \mathrm{MPa}$.

- Flexural strength for $4 \%$ addition of biopolymers $=0.56 \mathrm{MPa}$.

- Flexural strength for $6 \%$ addition of biopolymers $=0.53 \mathrm{MPa}$.

- Flexural strength for $8 \%$ addition of biopolymers $=0.52 \mathrm{MPa}$.

- Water absorption of pure earth soil samples $=12.9 \%$.

- Water absorption of $2 \%$ addition of biopolymers samples $=11.87 \%$.

- Water absorption of $4 \%$ addition of biopolymers samples $=11.55 \%$.

Water absorption of $6 \%$ addition of biopolymers samples $=13.23 \%$.

Water absorption of $8 \%$ addition of biopolymers samples $=13.45 \%$.

\begin{tabular}{|c|c|c|c|c|c|c|c|}
\hline Sample & $\begin{array}{c}\text { Length } \\
(\mathrm{mm})\end{array}$ & $\begin{array}{c}\text { Width } \\
(\mathrm{mm})\end{array}$ & $\begin{array}{c}\text { Thickness } \\
(\mathrm{mm})\end{array}$ & $\begin{array}{c}\text { Area } \\
\left(\mathrm{mm}^{2}\right)\end{array}$ & $\begin{array}{c}\text { Volume } \\
\left(\mathrm{mm}^{3}\right)\end{array}$ & $\begin{array}{c}\text { Load } \\
(\mathrm{KN})\end{array}$ & $\begin{array}{c}\text { Compressive } \\
\text { Strength(MPa })\end{array}$ \\
\hline $\mathrm{E}$ & 230 & 105 & 100 & 24150 & 2415000 & 83.076 & 3.51 \\
\hline $\mathrm{C} 2$ & 230 & 105 & 100 & 24150 & 2415000 & 81.627 & 4.6 \\
\hline C4 & 230 & 105 & 100 & 24150 & 2415000 & 83.3175 & 5.03 \\
\hline C6 & 230 & 105 & 100 & 24150 & 2415000 & 82.042 & 3.49 \\
\hline C8 & 230 & 105 & 100 & 24150 & 2415000 & 81.055 & 3.42 \\
\hline
\end{tabular}




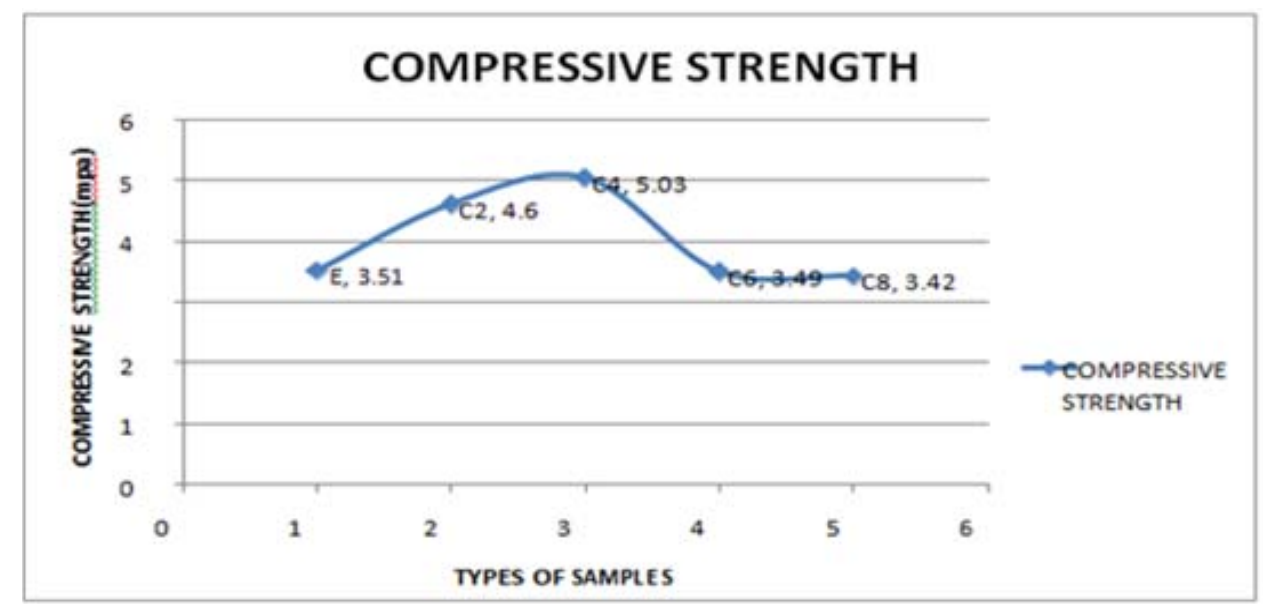

Fig 3 : Influence of Mud blocks on compressive strength

\begin{tabular}{|c|c|c|c|c|c|c|c|}
\hline $\begin{array}{c}\text { Sl. } \\
\text { No. }\end{array}$ & Length(mm) & Width(mm) & $\begin{array}{c}\text { Thickness } \\
(\mathrm{mm})\end{array}$ & $\begin{array}{c}\text { Area } \\
\left(\mathrm{mm}^{2}\right)\end{array}$ & $\begin{array}{c}\text { Volume } \\
\left(\mathrm{mm}^{3}\right)\end{array}$ & Load(KN) & $\begin{array}{c}\text { Flexural } \\
\text { strength(MPa })\end{array}$ \\
\hline 1 & 230 & 105 & 100 & 24150 & 2415000 & 12.43725 & 0.53 \\
\hline 2 & 230 & 105 & 100 & 24150 & 2415000 & 12.67875 & 0.54 \\
\hline 3 & 230 & 105 & 100 & 24150 & 2415000 & 13.041 & 0.56 \\
\hline 4 & 230 & 105 & 100 & 24150 & 2415000 & 13.010 & 0.53 \\
\hline 5 & 230 & 105 & 100 & 24150 & 2415000 & 12.80 & 0.52 \\
\hline
\end{tabular}

Table 6:- Test results for flexural strength.

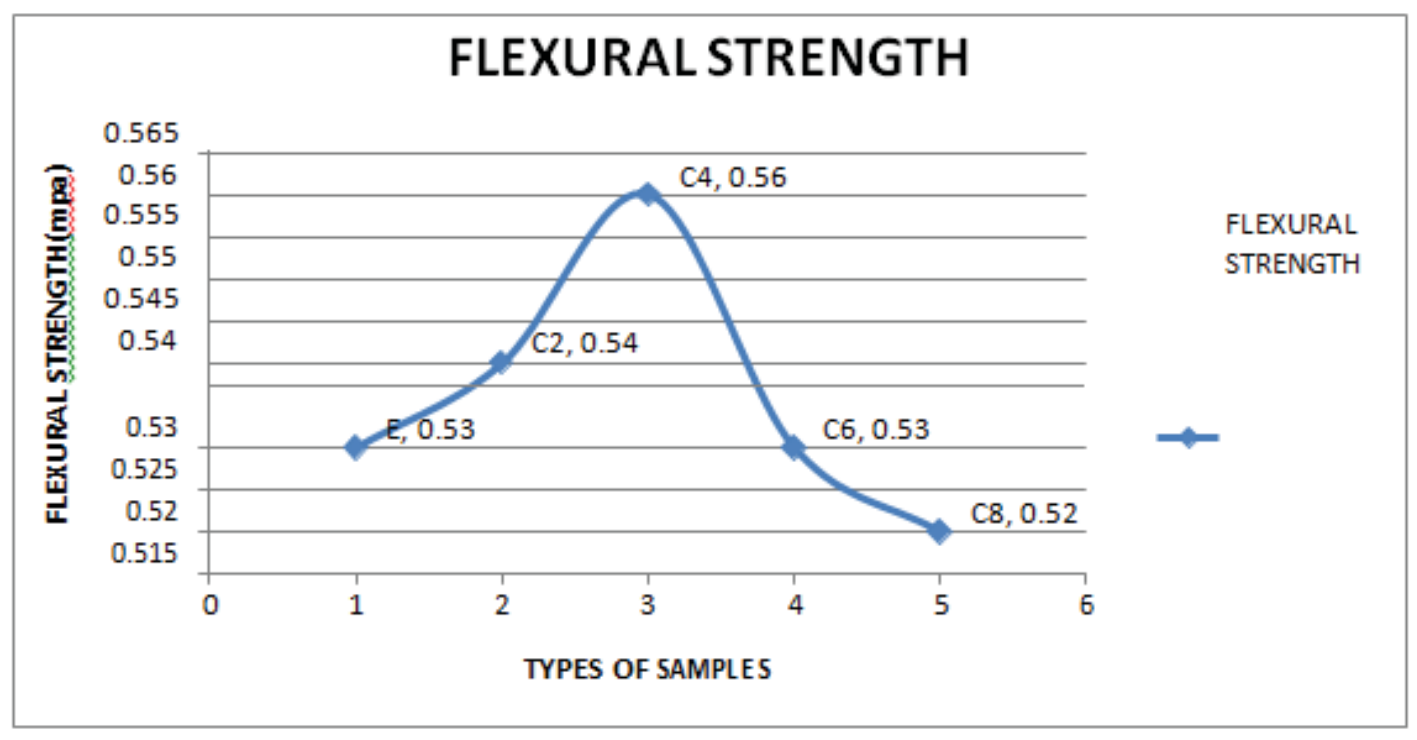

Fig 4 : Influence of Mud blocks on Flexural strength 


\begin{tabular}{|c|c|c|c|}
\hline Sl No. & Sample & Water absorption (\%) & $\begin{array}{l}\text { Average total water } \\
\text { absorption(\%) }\end{array}$ \\
\hline \multirow[t]{3}{*}{1} & \multirow[t]{3}{*}{ E } & 12.85 & \multirow{3}{*}{12.9} \\
\hline & & 12.9 & \\
\hline & & 12.95 & \\
\hline \multirow[t]{3}{*}{2} & \multirow[t]{3}{*}{$\mathrm{C} 2$} & 11.59 & \multirow{3}{*}{11.87} \\
\hline & & 12 & \\
\hline & & 12.01 & \\
\hline \multirow[t]{3}{*}{3} & \multirow[t]{3}{*}{$\mathrm{C} 4$} & 11.6 & \multirow{3}{*}{11.55} \\
\hline & & 11.5 & \\
\hline & & 11.55 & \\
\hline \multirow[t]{3}{*}{4} & \multirow[t]{3}{*}{ C6 } & 13.33 & \multirow{3}{*}{13.23} \\
\hline & & 13.22 & \\
\hline & & 13.15 & \\
\hline \multirow[t]{3}{*}{5} & \multirow[t]{3}{*}{$\mathrm{C} 8$} & 13.55 & \multirow{3}{*}{13.45} \\
\hline & & 13.45 & \\
\hline & & 13.35 & \\
\hline
\end{tabular}

Table 7:- Test results for water absorption.

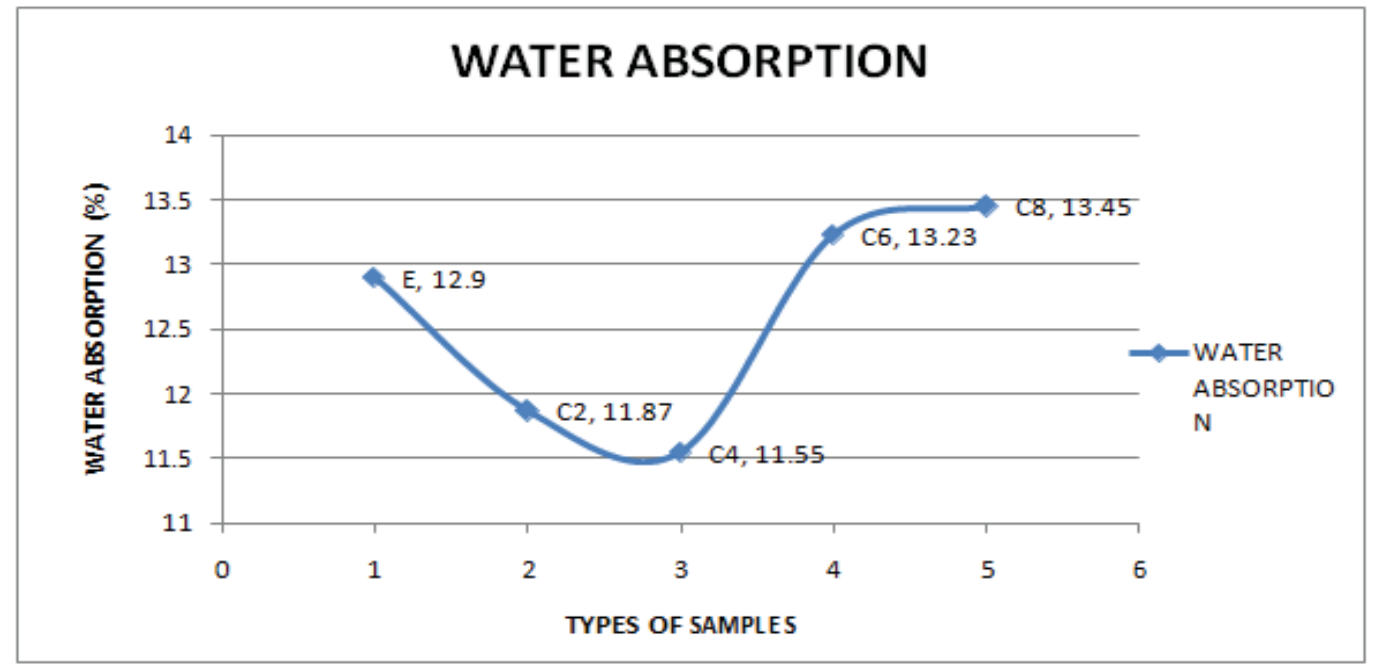

Fig 5 : Influence of Mud blocks on Water Absorption 


\section{- $\quad$ WEIGHT TEST FOR MUDBLOCK}

\begin{tabular}{|c|c|c|}
\hline S1 No. & Sample & Weight $(\mathrm{kg})$ \\
\hline 1 & E & 5 \\
\hline 2 & C2 & 4.9 \\
\hline 3 & C4 & 4.7 \\
\hline 4 & C6 & 4.3 \\
\hline 5 & C8 & 4.25 \\
\hline
\end{tabular}

Table 8:- Weights of mud blocks with different proportions.

\section{CONCLUSION}

Production of stabilized mud blocks victimization biopolymers as a stabilizer material fulfils variety of objectives that are necessary to achieve a sturdy structure from regionally obtainable soil. A number of these are: higher mechanical property (better compressive strength), higher cohesion between particles (reducing consistency that reduces changes in volume because of wet fluctuations). The properties of mud blocks is a valuable replacement material for concrete blocks and thence it is used wide. For Compressive strength, the optimum dosage of addition of biopolymer can be chosen up to $4 \%$ ( $2 \%$ Xanthan gum \& $2 \%$ Guar gum) for maximum compressive strength of 5.03mpa.For Flexural strength, the optimum dosage of addition of biopolymer can be chosen up to 4\% (2\% Xanthan gum \& 2\% Guar gum) for maximum Flexural strength achieved is up to $0.56 \mathrm{mpa}$. The wetness absorption capability of block may be considerably correlative to its sturdiness. Increase within the biopolymer content (optimum biopolymer addition of percentage up to 4\%) of blocks, results in an exceedingly reduction of its water absorption capability. Associate in nursing increment of the biopolymer content from $1 / 3$ to four wheel drive (2\% Xanthan gum \& two Cyamopsis psoraloides gum) ends up in the reduction in water absorption of one. $5 \%$. By the addition of biopolymers the weight can be reduces simultaneously.

\section{REFERENCES}

[1] B. Venkatarama Reddy and K. Jagadish, "Embodied energy of common and alternative building materials and technologies," Energy Build., vol. 35, no. 2, pp. 129-137, 2003.

[2] D. Felton, R. Fuller, and R. H. Crawford, "The potential for renewable materials to reduce the embodied energy and associated greenhouse gas emissions of medium-rise buildings," Archit. Sci. Rev., pp. 1-8, Sep. 2013.

[3] T. Woolley and N. Caleyron, "Overcoming the barriers to the greater development and use of environmentally friendly construction materials," presented at the Sustainable Building International Conference Proceedings, 2002.

[4] C. MacDougall, "Natural building materials in mainstream construction: lessons from the UK," J. Green Build., vol. 3, no. 3, pp. 1-14, 2008.

[5] E. W. Smith and G. S. Austin, Adobe, pressed-earth, and rammed-earth industries in New Mexico. New Mexico Bureau of Mines \& Mineral Resources, 1989.

[6] H. Houben and H. Guillaud, Earth construction: a comprehensive guide. Intermediate Technology Publications, 1994.

[7] C. Williams, S. Goodhew, R. Griffiths, and L. Watson, "The feasibility of earth block masonry for building sustainable walling in the United Kingdom,” J. Build. Apprais., vol. 6, no. 2, pp. 99-108, 2010.

[8] O. Ruskulis, "Additives to Clay: Mineral and Synthetic Additives," Practical Action, Technical Brief, 2002.

[9] B. Little and M. Morton, "Building with Earth in Scotland," 2001.

[10] F. Pacheco-Torgal and S. Jalali, "Earth construction: Lessons from the past for future eco-efficient construction," Constr. Build. Mater., vol. 29, pp. 512-519, Apr. 2012.

[11] P. J. Walker, "Strength, durability and shrinkage characteristics of cement stabilised soil blocks," Cem. Concr. Compos., vol. 17, no. 4, pp. 301-310, 1995. 